\title{
Factors inducing the activation of reconstructed oocytes of farm animals in somatic cloning procedures
}

\author{
J. Jurkiewicz ${ }^{1}$ \\ Department of Animal Reproduction, \\ National Research Institute of Animal Production \\ 32-083 Balice, Poland
}

(Received 17 February 2003; revised version 30 December 2003; accepted 16 June 2004)

\begin{abstract}
Artificial activation of reconstructed oocytes is induced with various physical or chemical factors, which can be used in a number of activation protocols such as pre-activation, simultaneous activation and fusion and post-activation. The post-activation protocol is the most common and brings best effects in somatic cloning of farm animals.

The artificial activation model is still different from the natural model of oocyte activation by penetrating spermatozoon, as is the case with fertilization. For this reason the protocols for artificial activation of reconstructed oocytes continue to be modified. Current studies on the improvement of oocyte artificial activation methods centre around the optimization of the electric field parameters and on the association of the activating factors with blockers of the activity of cyclin-dependent kinases or protein synthesis. The optimum activation method will make possible the complete reprogramming of exogenous cell nuclei and thus improve the ultimate efficiency of somatic cloning in farm animals.
\end{abstract}

KEY WORDS: somatic cloning, nuclear transfer, activation

\section{INTRODUCTION}

The procedure of somatic cloning by nuclear transfer technique involves many stages. One of the very important ones is artificial activation of reconstituted oocytes. Proper activation treatment beside other factors plays a key role in reprogramming of the somatic cell nucleus in cytoplasm of enucleated recipient-oocyte.

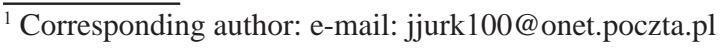


Up to now, the mechanism of reprogramming is not yet clear, but it is known that exogenous nucleus must undergo many changes leading to reactivation unblocking of previously inactivated genes, restoring it the status of totipotential nucleus, able to manage the development of the reconstructed embryo. The complete reprogramming of transferred nucleus is a necessary condition to achieving full development of the cloned embryos. At present, the use of cloning procedures does not always guarantee a normal and complete reprogramming of the nucleus (Zuccotti et al., 2000).

In the somatic cloning procedure by transplantation of cell nuclei, the donor of exogenous cell nuclei are in vitro or in vivo mature oocytes whose development was arrested at metaphase II of meiotic division. The somatic cell nucleus is introduced into the cytoplasm of enucleated recipient-oocyte directly (micro-injection) or through an electric impulse (electrofusion). The completion and restoration of meiosis is conditional on the activation of reconstructed oocytes.

\section{OOCYTE ACTIVATION}

\section{Sperm-induced oocyte activation}

In natural conditions, the oocyte is activated by a spermatozoon during fertilization, which elevates the level of $\mathrm{Ca}^{2+}$ ions released from intracellular deposits in the form of rapid, short and often consecutive (oscillatory) ejections. After the penetration of the spermatozoon, the likely mechanism of releasing calcium ions involves binding of the spermatozoon with a specific receptor on the oocyte's cell membrane, which initiates the transformation of phosphoinositol leading to elevated level of 1,4,5-inositol triphosphate $\left(\mathrm{IP}_{3}\right)$, which, in turn, by inducing the opening of calcium channels, releases calcium ions from intracellular deposits (Miyazaki S., 1988). Intracellular $\mathrm{Ca}^{2+}$ is stored in the smooth endoplasmic reticulum, from which the release of calcium ions is mediated by specialized calcium channels protected by $\mathrm{IP}_{3}$ and ryanodine receptors, which are opened with the help of antagonists of the above receptors. Calcium release control is dependent on the presence of sulphydryl groups located in receptor complexes (Swann, 1993; Whitaker et al., 1993).

\section{Artificial induction of oocyte activation}

In the cell nuclei transplantation method, oocytes must be artificially activated. Artificial activation of reconstructed oocytes can be induced with various physical or chemical agents. The most common physical agent are electric pulses (Wilmut et al., 1997; Polejaeva et al., 2000; Skrzyszowska et al., 2000). However, the most frequently used chemical factors are calcium ionophores such as ionomycin (Wells et 
al., 1998) or A23187 (Skrzyszowska et al., 2001), as well as 7\% ethanol (Zakhartchenko et al., 1999) or thimerosal with dithiothreitol (DTT) (Tao et al., 1999). The full chemical activation protocol also involves incubation of oocytes in the presence of cyclin-dependent kinase inhibitors or synthesis of proteins such as 6-dimethylaminopurine (6-DMAP) (Wells et al.,1999) or cycloheximide (CH) (Skrzyszowska et al., 2001).

Treatment of oocytes with electric pulses results in reversible appearance of pores in the oocyte's plasmatic membrane, which allow the inflow of extracellular $\mathrm{Ca}^{2+}$ and lead to elevated level of calcium ions in the cell (Ozil J., 1990; Collas et al., 1993). Therefore oocyte activation with an electric pulse is conditional on the presence of $\mathrm{Ca}^{2+}$ ions in the extracellular environment. Recent pig embryo studies have demonstrated that an electric pulse also causes a partial mobilization of intracellular deposits (De Sousa et al., 2002). An electric impulse as an activating factor is often used in sheep (Shnieke et al., 1997), pigs (Onishi et al., 2000) and rabbits (Dinnyes et al., 2001), less frequently in cattle (Kato et al., 1999).

Another way of inducing the inflow of $\mathrm{Ca}^{2+}$ and activating oocytes is the use of calcium ionophores. Ionophores stimulate the increase in $\mathrm{Ca}^{2+}$ level by mobilization of intracellular deposits. Thus, where chemical activators are used, the presence of calcium ions in the extracellular environment is not the necessary condition. A frequently used ionophore is ionomycin. Ionomycin has been successfully used in the activation ovine oocytes (Loi et al., 1998, 2002) but also in activation of bovine (Wells et al., 1999) and goats (Keefer et al., 2001) oocytes.

Ethanol, by stimulating the production of 1,4,5-inositol triphosphate ( $\left.\mathrm{IP}_{3}\right)$ also activates a certain number of oocytes, initiating rapid and intense release of $\mathrm{Ca}^{2+}$ from intracellular deposits (Ilyin and Parker, 1992). Ethanol as an activating agent is particularly effective with regard to ovine oocytes (Loi et al., 1998), but less useful for activating cattle and porcine oocytes.

A less common chemical activator, used only for activation of reconstructed porcine oocytes is thimerosal in combination with dithiothreitol (DTT) (Tao et al., 1999). It induces repeatable excitation of $\mathrm{Ca}^{2+}$ level in cell probably as a result of oxidation of sulphydryl groups in intracellular release proteins (Machaty et al., 1997). Thimerosal also oxidizes tubulin sulphydryl groups by partially degrading the meiotic spindle. This activity, however, can be reversed by antagonistic action of dithiothreitol as the sulphydryl reducing agent, which is capable of reconstructing the ultrastructure of the division spindle (Cheek, 1993).

A different way of activating mammalian oocytes is through direct microinjection of $\mathrm{Ca}^{2+}$ buffers or unbuffered $\mathrm{Ca}^{2+}$ solutions into the oocyte's cytoplasm. Machaty et al. (1996) when applying intracellular injections of $\mathrm{CaCl}_{2}$ in pigs, achieved parthenogenetic development of embryos to the blastocyst stage. Also the injection of specific sperm proteins (e.g., oscillin) results in an oscillatory ejection of $\mathrm{Ca}^{2+}$, leading to activation of porcine oocytes. However, the microinjection technique has 
not been in wide use as a method of activating reconstructed oocytes. Recently, an interesting proposition of chemical activation is injection of sperm cytosolic extract into cytoplasm of reconstructed oocytes (Choi et al., 2002).

In the activated oocyte there occurs, both naturally and artificially, a reduction in the activity of the maturation or mitosis/meiosis promoting factor (MPF), leading to restoration of meiosis. This is because MPF, the complex of protein kinase $\mathrm{p} 34 \mathrm{cdc} 2$ and B cyclin, is a regulator of the meiotic and mitotic cell cycle. MPF is additionally stabilized by the cytostatic factor (CSF). Reduced MPF and CSF activity is caused by inactivation of cyclin-dependent kinases and protein synthesis (Boglio et al., 2000). In the somatic cloning procedure, the commonly used kinase inhibitor is 6-dimethylaminopurine (6-DMAP).

\section{Variants of activation protocols used in the procedure of somatic cloning}

Various activation protocols are used for the above factors. They concern the choice of both the activating factor and the adequate moment of its application. The moment concerns the sequence of fusion and activation as well as the interval between both procedures. In the somatic cloning procedure the following 3 activation protocols are used: pre-activation, simultaneous activation and fusion, and post-activation.

If the exogenous cell nucleus is introduced into pre-activated oocytes, followed by electric pulse-induced fusion of enucleated oocyte with the somatic cell, then we talk of pre-activation (Figure 1). This type of an activation protocol has been commonly used in embryo cloning in contradistinction to somatic cloning (Campbell et al., 1993). If the introduce of nucleus into enucleated recipient-oocyte is accompanied by activation, this protocol is called simultaneously activation and fusion. In this protocol, the electric pulse used to initiate the fusion is at the same time the only agent activating the reconstructed oocyte (Figure 2). When the reconstructed oocytes are activated only 1-6 h after the cell nucleus was introduced into the cytoplasmic environment, then we deal with post-activation. This protocol involves a 5-min incubation of oocytes in medium supplemented with a chemical activator, and followed by several-hour incubation with a supplement of cyclin-dependent kinases 6-dimethy-laminopurine (6-DMAP) or protein synthesis cycloheximide $(\mathrm{CH})$ (Figure 3). The variant of post-activation proposed by Cibelli et al. (1998) and later used by other authors is now the most popular. In such conditions, MPF induces the nuclear envelope breakdown (NEBD) and premature chromosome condensation (PCC). It is assumed that NEBD and PCC are the necessary condition, because oscillations of calcium ions appear only after the nuclear envelope breakdown and premature chromosome condensation. Furthermore, lengthening the effect of cytoplasmic factors on the somatic cell nucleus enables its more complete reprogramming.

The most common protocol used in the somatic cloning of farm animals is the post-activation protocol with the use of chemical agents as an activator. 
Recipient of cell nucleus-

in vitro or in vivo mature oocyte

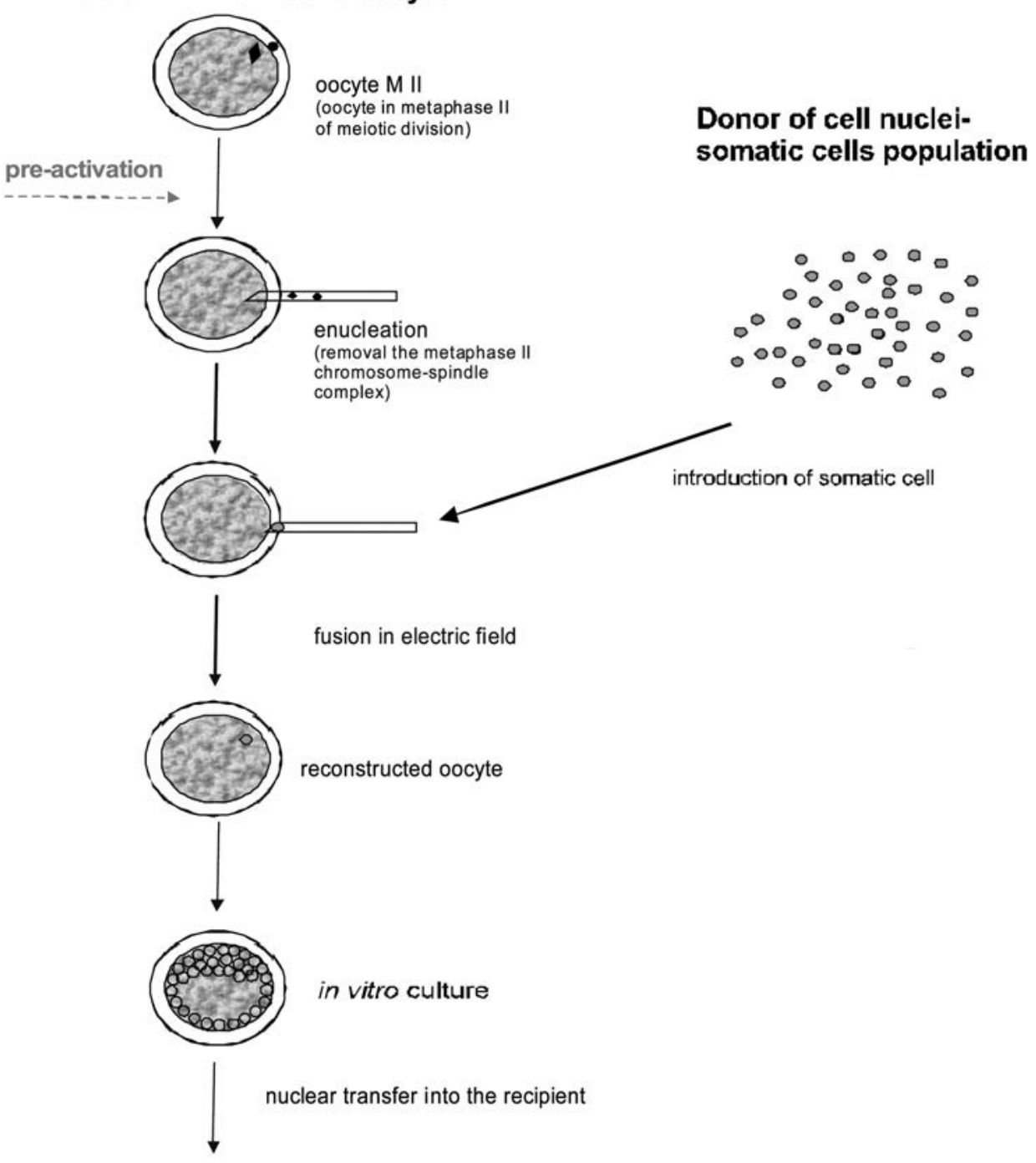

Figure 1. Diagram of somatic cloning procedure-variant of pre-activation protocol 
Recipient of cell nucleusin vitro or in vivo mature oocyte

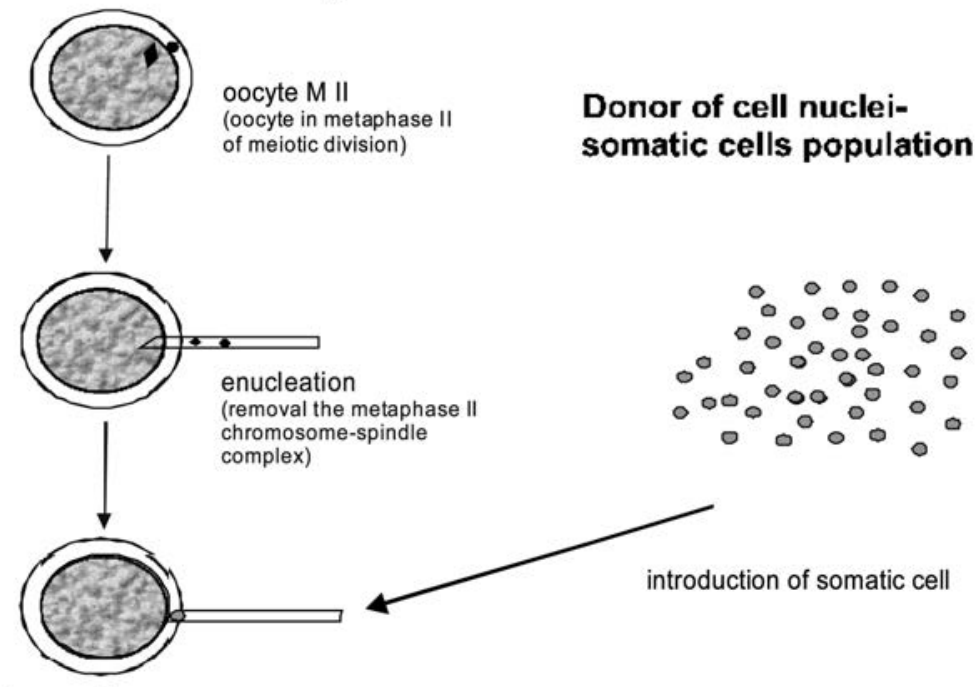

simultaneous activation and fusion

fusion in electric field

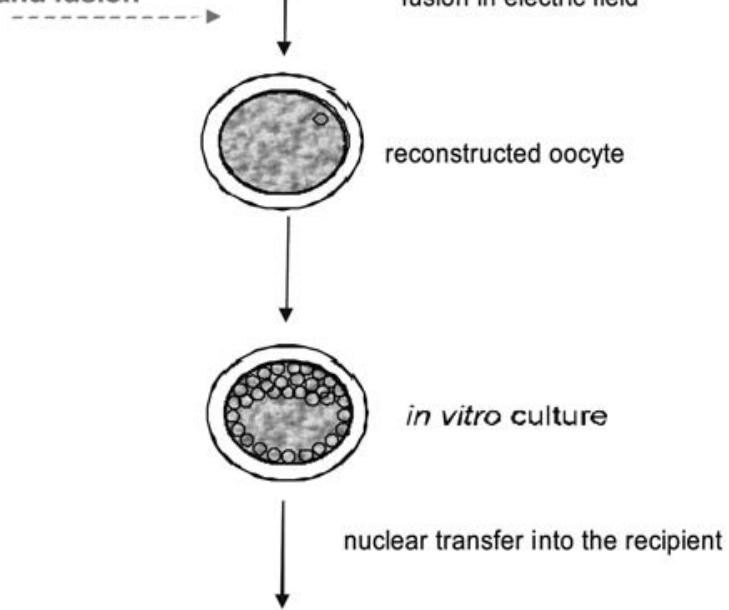

Figure 2. Diagram of somatic cloning procedure-variant of simoultaneous activation and fusion protocol 
Recipient of cell nucleusin vitro or in vivo mature oocyte

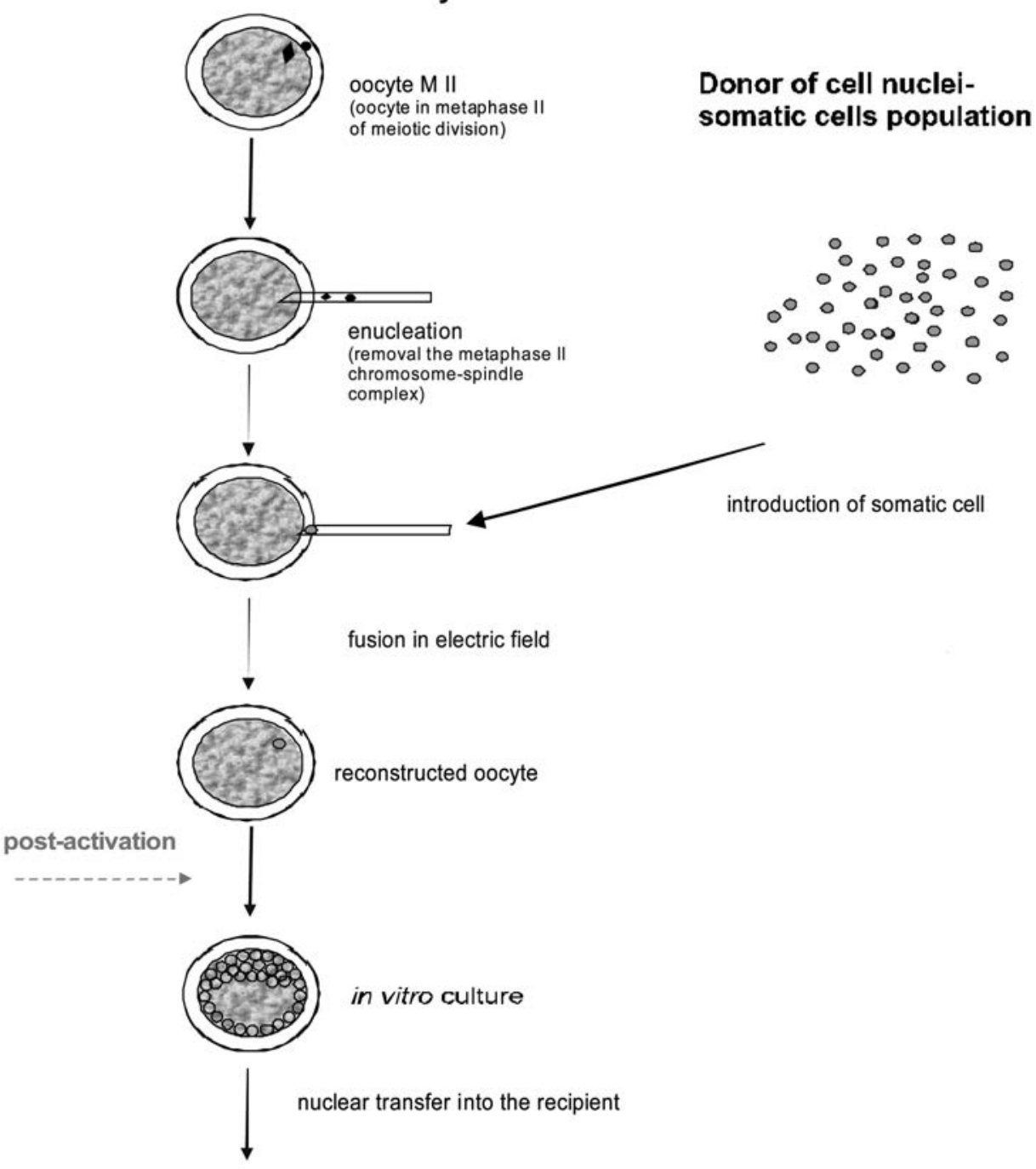

Figure 3. Diagram of somatic cloning procedure-variant of post-activation protocol 


\section{Activation protocols used in the procedure of somatic cloning in farm animals}

In cattle, this activation protocol involving the use of ionomycin/6-DMAP or cycloheximide as well as the simultaneous activation and fusion protocol brings favourable results. The procedure of simultaneous activation and fusion is a success both with chemical and physical activators. Only the activation treatment with pre-activation in somatic cloning procedure is rarely applied in contradistinction to embryo cloning (Table 1).

TABLE 1

Activation protocols used in the procedure of somatic cloning in cattle

\begin{tabular}{|c|c|c|c|c|c|}
\hline $\begin{array}{l}\text { Activation } \\
\text { protocol }\end{array}$ & Activation factor & $\begin{array}{c}\text { Origin } \\
\text { of donor } \\
\text { cells }\end{array}$ & $\begin{array}{c}\text { Blasto- } \\
\text { cysts } \\
\%\end{array}$ & $\begin{array}{l}\text { No. of } \\
\text { offspring }\end{array}$ & $\begin{array}{l}\text { Refe- } \\
\text { rences }\end{array}$ \\
\hline \multirow[t]{3}{*}{$\begin{array}{l}\text { Pre- } \\
\text { activation }\end{array}$} & $\begin{array}{l}\text { calcium ionophore A23187, } 10 \mu \mathrm{M} / \mathrm{L} \\
7 \% \text { ethanol cykloheximide, } 10 \mu \mathrm{g} / \mathrm{ml}\end{array}$ & \multirow{3}{*}{ muscle } & 2.5 & - & \multirow{3}{*}{$\begin{array}{r}\text { Shiga } \\
(1999)\end{array}$} \\
\hline & $\begin{array}{l}\text { calcium ionophore } \mathrm{A} 23187,10 \mu \mathrm{M} / \mathrm{L} \\
\text { cykloheximide, } 10 \mu \mathrm{g} / \mathrm{ml}\end{array}$ & & 19.0 & - & \\
\hline & $\begin{array}{l}\text { calcium ionophoreA23187, } 10 \mu \mathrm{M} / \mathrm{L} \\
\text { cykloheximide, } 10 \mu \mathrm{g} / \mathrm{ml}\end{array}$ & & $20.5^{\mathrm{a}}$ & 1 (dead) & \\
\hline \multirow{7}{*}{$\begin{array}{l}\text { Simultaneous } \\
\text { activation } \\
\text { and fusion }\end{array}$} & cykloheximide, $10 \mu \mathrm{g} / \mathrm{ml}$ & & $18.3^{\mathrm{ab}}$ & 3 (2 dead $)$ & \multirow[b]{2}{*}{$\begin{array}{l}\text { Kubota } \\
(2000)\end{array}$} \\
\hline & $\begin{array}{l}2 \mathrm{DC} \text { pulses, } 2.5 \mathrm{kV} / \mathrm{cm}, 10 \mu \mathrm{s}^{\mathrm{e}} \\
\text { cykloheximide, } 10 \mu \mathrm{g} / \mathrm{ml}\end{array}$ & ear tissue & $21-33^{c}$ & $6(2$ dead $)$ & \\
\hline & $\begin{array}{l}\text { ionomycin, } 5 \mu \mathrm{M} / \mathrm{L} \\
\text { 6-DMAP }, 2 \mathrm{mM} / \mathrm{L}\end{array}$ & \multirow{3}{*}{$\begin{array}{c}\text { mural } \\
\text { granulosa }\end{array}$} & 10.6 & - & \multirow{3}{*}{$\begin{array}{r}\text { Wells } \\
(1998)\end{array}$} \\
\hline & $2 \mathrm{DC}$ pulses, $2.25 \mathrm{kV} / \mathrm{cm}, 15 \mu \mathrm{s}$ & & 18.6 & - & \\
\hline & $\begin{array}{l}\text { ionomycin, } 10 \mu \mathrm{g} / \mathrm{ml} \\
\text { 6-DMAP, } 2 \mathrm{mM} / \mathrm{L}\end{array}$ & & 39.8 & 2 & \\
\hline & DC pulse, $20 \mathrm{~V} / \mathrm{mm}, 20 \mu \mathrm{s}$ & cumulus & 49.0 & 5 (3 dead $)$ & Kato \\
\hline & cykloheximide, $10 \mu \mathrm{g} / \mathrm{ml}$ & oviduct & 23.0 & 3 (1 dead $)$ & (1998) \\
\hline \multirow[t]{3}{*}{$\begin{array}{l}\text { Post- } \\
\text { activation }\end{array}$} & $\begin{array}{l}\text { calcium ionophore A2318, } 5 \mu \mathrm{M} / \mathrm{L} \\
\text { 6-DMAP, } 2 \mathrm{mM} / \mathrm{L}\end{array}$ & foetus & 12.0 & 3 & $\begin{array}{l}\text { Cibelli } \\
(1998)\end{array}$ \\
\hline & cytochalasin B, $5 \mu \mathrm{g} / \mathrm{ml}$ & mural & $11.8^{\mathrm{d}}$ & 7 & \multirow{2}{*}{$\begin{array}{c}\text { Gibbons } \\
(2002)\end{array}$} \\
\hline & $\begin{array}{l}\text { cykioneximide, } 10 \mu \mathrm{g} / \mathrm{ml} \\
\text { calcium ionophore, } 5 \mathrm{mM} / \mathrm{L}\end{array}$ & granulosa & $21.1^{\mathrm{a}}$ & $2(1$ dead $)$ & \\
\hline
\end{tabular}

${ }^{a}$ reconstructed blastocysts derived from nuclei starved cells

${ }^{\mathrm{b}}$ blastocysts obtained from nuclear transfer into aged cytoplasts (12 h)

${ }^{\mathrm{c}}$ percentage of reconstructed blastocysts obtained from nuclei of cells derived from different cell lines (passage 5-15)

${ }^{\mathrm{d}}$ reconstructed blastocysts derived from nuclei roscovitine-treated granulosa cells

${ }^{\mathrm{e}} \mathrm{DC}$-direct current pulse

${ }^{\mathrm{f}}$ 6-DMAP-6-dimethyloaminopurine 
Moreover, in cattle, the recloning method was applied to increase the cloning procedure efficiency. This method consist of double of nuclear transfer (NT). The embryos obtained from reconstructed oocytes in the 1st rount of NT were used in the 2 nd round of NT as donors of cell nuclei. In the 1st round of NT reconstructed oocytes were activated after nuclei transfer (post-activation) but in the 2 nd round of NT, oocytes assigned for recipient cytoplasm were pre-activated before nuclear transfer of cell nuclei deriving from embryos obtained from the 1st round of NT. The transferred nucleus of somatic cell was subjected to the action of cytoplasmic agents in a longer period of the time, which probably had a positive influence on its normal reprogramming (Table 2).

TABLE 2

Activation protocols used in the procedure of cattle somatic cloning in cattle; recloning

\begin{tabular}{|c|c|c|c|c|c|c|}
\hline $\begin{array}{l}\text { Recloning } \\
\text { method }^{1}\end{array}$ & $\begin{array}{c}\text { Activation } \\
\text { protocol }\end{array}$ & Activation factor & $\begin{array}{c}\text { Origin } \\
\text { of donor } \\
\text { cells }\end{array}$ & $\begin{array}{c}\text { Blasto- } \\
\text { cysts } \\
\%\end{array}$ & $\begin{array}{l}\text { No. of } \\
\text { offspring }\end{array}$ & References \\
\hline \multirow{3}{*}{$\begin{array}{l}\text { I round of } \\
\text { nuclear } \\
\text { transfer }^{1}\end{array}$} & \multirow[t]{3}{*}{$\begin{array}{l}\text { post- } \\
\text { activation }\end{array}$} & \multirow{3}{*}{$\begin{array}{l}\text { ionomycin, } 5 \mu \mathrm{M} / \mathrm{L} \\
\text { 6-DMAP }, 2 \mathrm{mM} / \mathrm{L} \\
\text { ionomycin, } 5 \mu \mathrm{M} / \mathrm{L} \\
\text { 6-DMAP, } 2.5 \mathrm{mM} / \mathrm{L} \\
\text { 7\% ethanol } \\
\text { cykloheximide, } 10 \mu \mathrm{g} / \mathrm{ml} \\
\text { cytochalasin } \mathrm{B}, 5 \mu \mathrm{g} / \mathrm{ml}\end{array}$} & $\begin{array}{l}\text { mural } \\
\text { granulosa }\end{array}$ & 27.5 & 10 & $\begin{array}{l}\text { Wells } \\
(1999\end{array}$ \\
\hline & & & leukocytes & 17.0 & - & $\begin{array}{c}\text { Galli } \\
\text { (1999) }\end{array}$ \\
\hline & & & foetus & $39.0^{2}$ & - & $\begin{array}{c}\text { Zakharchenko } \\
\text { (1999) }\end{array}$ \\
\hline \multirow{4}{*}{$\begin{array}{l}\text { II round } \\
\text { of nuclear } \\
\text { transfer }^{1}\end{array}$} & \multirow[t]{4}{*}{$\begin{array}{l}\text { pre- } \\
\text { activation }\end{array}$} & \multirow{4}{*}{$\begin{array}{l}\text { ionomycin, } 5 \mu \mathrm{M} / \mathrm{L} \\
\text { 6-DMAP, } 2 \mathrm{mM} / \mathrm{L} \\
\text { ionomycin, } 5 \mu \mathrm{M} / \mathrm{L} \\
\text { 6-DMAP, } 2.5 \mathrm{mM} / \mathrm{L} \\
7 \% \text { ethanol } \\
\text { cykloheximide, } 10 \mu \mathrm{g} / \mathrm{ml} \\
\text { cytochalasin } \mathrm{B}, 5 \mu \mathrm{g} / \mathrm{ml}\end{array}$} & $\begin{array}{l}\text { mural } \\
\text { granulosa }\end{array}$ & 13.0 & - & $\begin{array}{c}\text { Wells } \\
(1999)\end{array}$ \\
\hline & & & leukocytes & 19.0 & 1 & $\begin{array}{c}\text { Galli } \\
\text { (1999) }\end{array}$ \\
\hline & & & & 55.0 & 2 & Zakharchenko \\
\hline & & & foetus & $52.0^{2}$ & - & (1999) \\
\hline
\end{tabular}

${ }^{1}$ recloning method

I round of nuclear transfer-somatic cells as nuclei donors

II round of nuclear transfer-embryos derived from I round of nuclear transfer as nuclei donors

${ }^{2}$ reconstructed blastocysts derived from nuclei starved foetal fibroblast

${ }^{3}$ 6-DMAP-6-dimethyloaminopurine

In the somatic cloning of pigs, the post-activation protocol using electric pulse as an activating agent is also the most commonly used protocol. Studies have shown that the choice of adequate parameters of electric field and pulse duration has a significant effect on the developmental potential of embryos. Lower strength of electric field and shorter duration of the pulse considerably decrease the proportion of blastocysts being obtained. An exception in the 
somatic cloning of pigs are the studies of Bethauser et al. (2000), who used ionomycin as an activating agent. Although the rate of reconstructed blastocysts was low, the final outcome of the experiment was impressive, because a clone of 4 animals was obtained. Instead, Polejaeva et al. (2000) was obtained 5 piglets after used recloning method. In this case, the recloning of porcine embryos was different then recloning of cattle embryos. The somatic cell nucleus in the 1st round of NT was transplanted into the cytoplasmic environment of the oocyte but in the 2 nd round into the zygote. Exposure of nuclear chromatin to prolonged action of cytoplasmic factors of the oocyte, and then zygote, had a favourable effect on reprogramming the cell nuclei (Table 3).

TABLE 3

Activation protocols used in the procedure of somatic cloning in pig

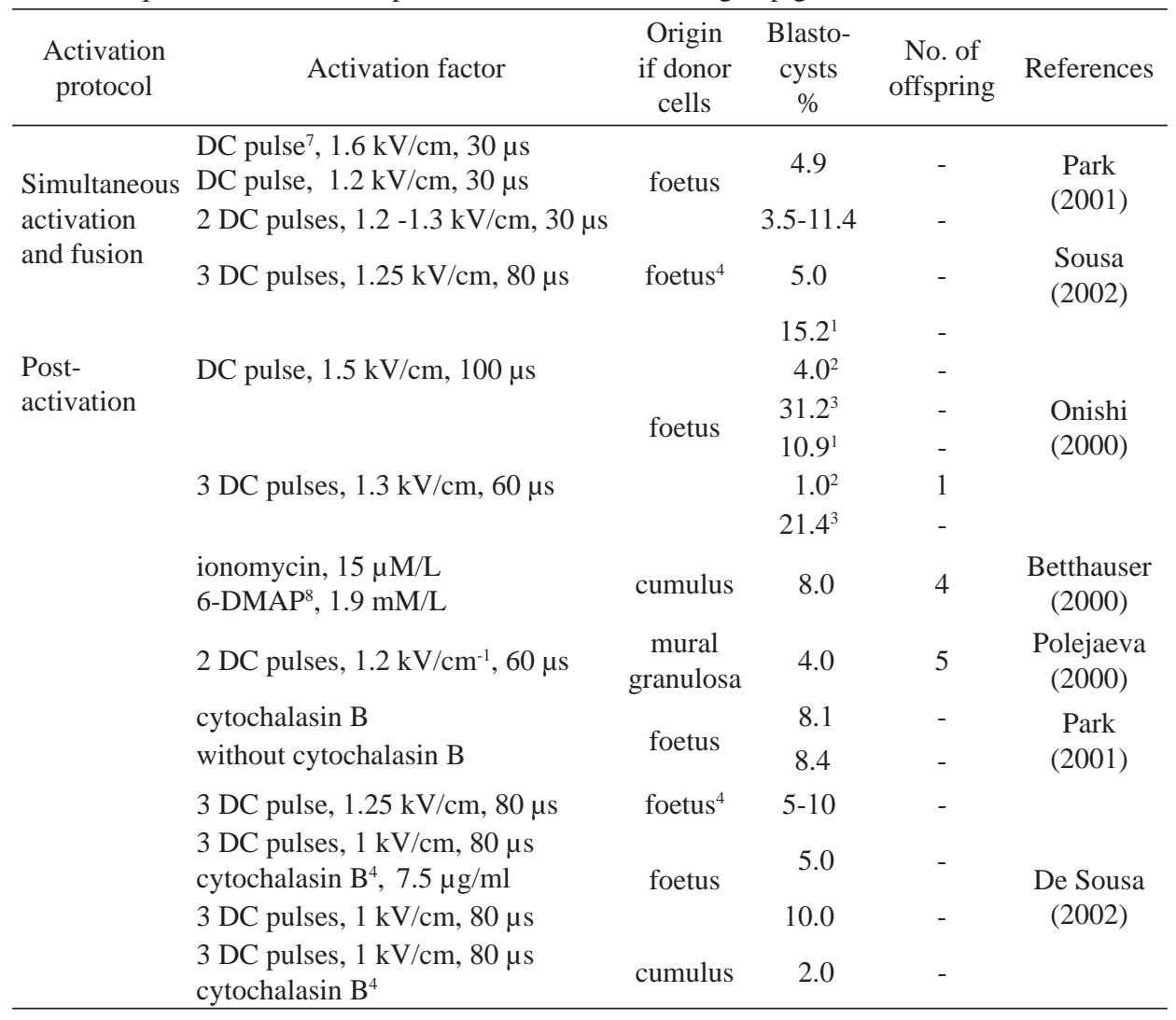


TABLE 3

continued

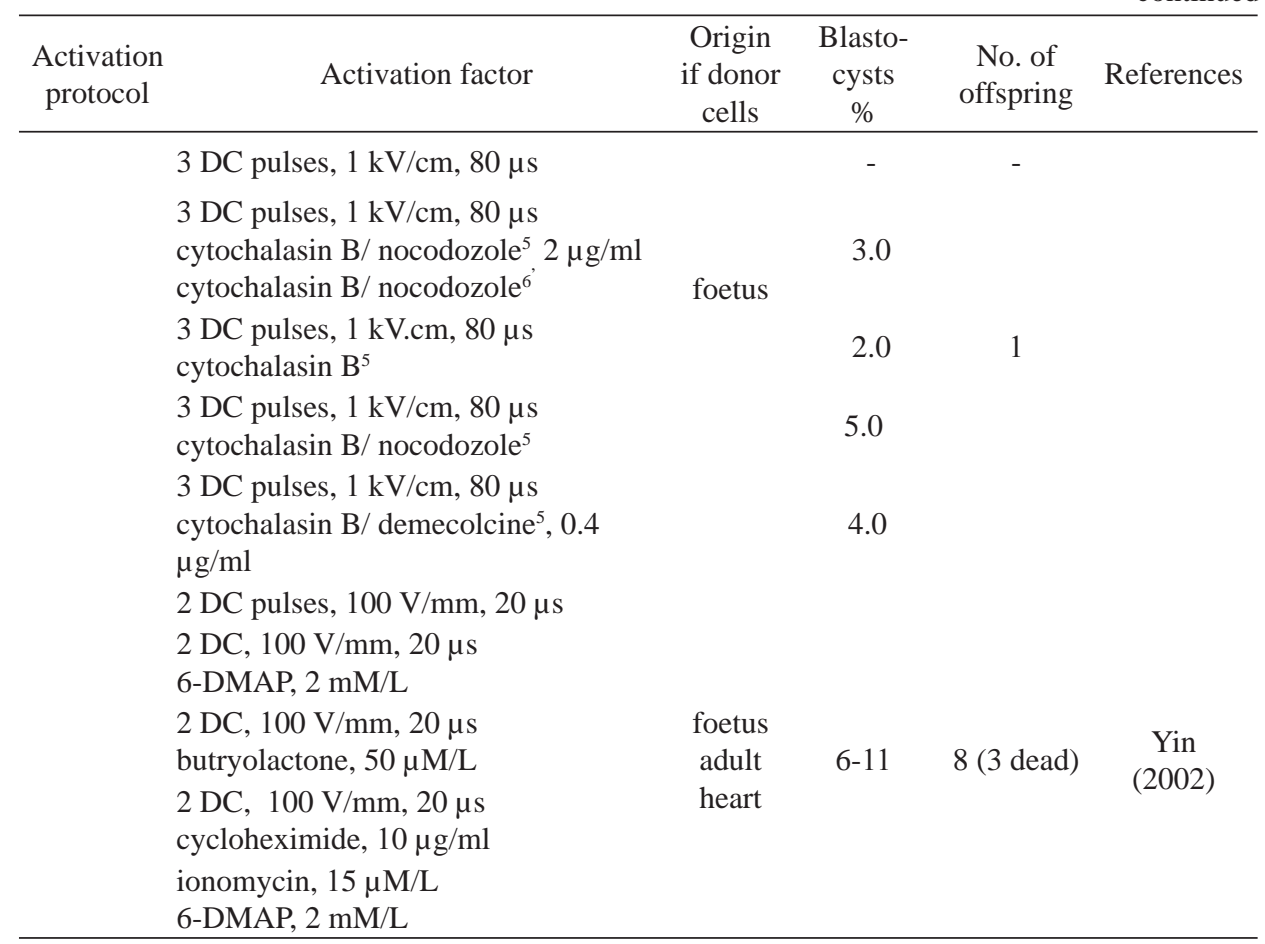

${ }^{1}$ culture in BECM medium

${ }^{2}$ culture in $\mathrm{mWM}$ medium

${ }^{3}$ culture in NCSU medium

${ }^{4}$ incubation reconstrocted oocytes with cytochalasin B $2 \mathrm{~h}$ after fusion and $6 \mathrm{~h}$ after activation

${ }^{5}$ incubation $2 \mathrm{~h}$ after fusion

${ }^{6}$ incubation $6 \mathrm{~h}$ after activation

${ }^{7}$ DC-direct current pulse

${ }^{8}$ 6-DMAP-6-dimethyloaminopurine

In somatic cloning of sheep, the most common and effective activation treatment is the simultaneous activation and fusion protocol. The electric pulse used to initiate electrofusion acts also as an activating factor. This type of activation protocol has led to the production of sheep clones (Table 4).

As regards the somatic cloning of goats, both the simultaneous activation and fusion and the post-activation protocols were applied. Using the protocol of simultaneously activation and fusion with electric pulse, Baguisi et al. (1999) obtained a clone of 3 animals. Studies of Keefer et al. (2001) and Reggio et al. (2001) show that the post-activation protocol using ionomycin/6-DMAP is also effective (Table 5). 
TABLE 4

Activation protocols used in the procedure of somatic cloning in sheep

\begin{tabular}{|c|c|c|c|c|c|}
\hline $\begin{array}{l}\text { Activation } \\
\text { protocol }\end{array}$ & $\begin{array}{l}\text { Activation } \\
\text { factor }\end{array}$ & $\begin{array}{c}\text { Origin of } \\
\text { donor cells }\end{array}$ & $\begin{array}{c}\text { Blastocysts } \\
\%\end{array}$ & $\begin{array}{c}\text { No. of } \\
\text { offspring }\end{array}$ & References \\
\hline \multirow{8}{*}{$\begin{array}{l}\text { Simultaneous } \\
\text { activation } \\
\text { and fusion }\end{array}$} & electric pulse & $\begin{array}{l}\text { mammary } \\
\text { epithelium }\end{array}$ & 11.7 & 1 & \multirow{3}{*}{$\begin{array}{l}\text { Wilmut } \\
\text { (1997) }\end{array}$} \\
\hline & & \multirow{2}{*}{ foetus } & 27.4 & 1 & \\
\hline & & & 54.2 & 2 & \\
\hline & & foetus & 6.1 & 1 & \multirow[t]{2}{*}{$\begin{array}{c}\text { Schnieke } \\
\text { (1997) }\end{array}$} \\
\hline & & \multirow{4}{*}{ foetus $^{1}$} & 14 & 4 (3 dead) & \\
\hline & & & 43 & 8 (4 dead) & \multirow{3}{*}{$\begin{array}{c}\text { McCreath } \\
\text { (2000) }\end{array}$} \\
\hline & & & 4 & - & \\
\hline & & & 19 & 2 (2 dead) & \\
\hline
\end{tabular}

${ }^{1}$ genetically transfected

TABLE 5

Activation protocols used in the procedure of somatic cloning in goats

\begin{tabular}{|c|c|c|c|c|c|}
\hline $\begin{array}{l}\text { Activation } \\
\text { protocol }\end{array}$ & Activation factor & $\begin{array}{l}\text { Origin } \\
\text { of donor } \\
\text { cells }\end{array}$ & $\begin{array}{c}\text { No. of } \\
\text { dividing } \\
\text { embryos } \\
\%\end{array}$ & $\begin{array}{c}\text { No. of } \\
\text { offspring }\end{array}$ & References \\
\hline \multirow{3}{*}{$\begin{array}{l}\text { Simultaneous } \\
\text { activation } \\
\text { and fusion }\end{array}$} & $\mathrm{AC} \mathrm{pulse}^{2}, 5-10 \mathrm{~V}, 7 \mathrm{~s}$ & \multirow{5}{*}{ foetus } & $48(34.8)^{1}$ & $1^{\text {la }}$ & $\begin{array}{c}\text { Baguisi } \\
(1999)\end{array}$ \\
\hline & DC pulse ${ }^{3}, 1.4-1.8 \mathrm{kV} / \mathrm{cm}, 70 \mu \mathrm{s}$ & & $41(44.6)^{1 b}$ & $2^{1 b}$ & \\
\hline & & & $31(56.4)^{41 c}$ & $-1 \mathrm{c}$ & \\
\hline \multirow{2}{*}{$\begin{array}{l}\text { Post- } \\
\text { activation }\end{array}$} & $\begin{array}{l}\text { ionomycin, } 5 \mu \mathrm{M} / \mathrm{L} \\
6-\mathrm{DMAP}^{4}, 2 \mathrm{mM} / \mathrm{L}\end{array}$ & & 57.0 & $\begin{array}{c}6 \\
\text { (3 dead) }\end{array}$ & $\begin{array}{l}\text { Keefer } \\
(2001)\end{array}$ \\
\hline & $\begin{array}{l}\text { ionomycin, } 5 \mu \mathrm{M} / \mathrm{L} \\
6-\mathrm{DMAP}, 2 \mathrm{mM} / \mathrm{L}\end{array}$ & & 43.0 & 5 & $\begin{array}{r}\text { Reggio } \\
(2001)\end{array}$ \\
\hline
\end{tabular}

${ }^{1}$ recipient of egzogenous cell nuclei: ${ }^{\mathrm{a}}$ arrested methaphase II oocytes; ${ }^{\mathrm{b}}$ calcium-activated telophase II oocytes; ${ }^{c}$ ethanol-induced calcium-activated telophase II oocytes

${ }^{2} \mathrm{AC}$-alternating current pulse

${ }^{3}$ DC-direct current pulse

${ }^{4}$ 6-DMAP-6-dimethyloaminopurine

In the somatic cloning of rabbits, just as in other species, the highest rate of blastocyst-stage embryos was noted after using the post-activation protocol and the protocol of simultaneous activation and fusion. The most numerous (4 animals) and the only somatic clone of rabbit produced so far was obtained by Chesne et al. (2002) who used post-activation with multiple electric pulse and incubation of the reconstructed oocytes in culture medium supplemented with cycloheximide or 6-DMAP culture medium (Table 6). 
TABLE 6

Activation protocols used in the procedure of somatic cloning in rabbit

\begin{tabular}{|c|c|c|c|c|c|}
\hline $\begin{array}{c}\text { Activation } \\
\text { protocol }\end{array}$ & Activation factor & $\begin{array}{l}\text { Origin of } \\
\text { donor cells }\end{array}$ & $\begin{array}{l}\text { Blasto- } \\
\text { cysts, \% }\end{array}$ & $\begin{array}{c}\text { No. of } \\
\text { offspring }\end{array}$ & References \\
\hline $\begin{array}{l}\text { Pre- } \\
\text { activation }\end{array}$ & $\begin{array}{l}\text { DC pulse }{ }^{3}, 2.4 \mathrm{kV} / \mathrm{cm}, 60 \mu \mathrm{s} \\
6-\mathrm{DMAP}(2 \mathrm{~h}), 2.5 \mathrm{mM} / \mathrm{L}\end{array}$ & & 18.0 & - & \multirow{4}{*}{$\begin{array}{l}\text { Dinnyes } \\
(2001)\end{array}$} \\
\hline \multirow{2}{*}{$\begin{array}{l}\text { Pre- } \\
\text { activation/ } \\
\text { Post- } \\
\text { activation }\end{array}$} & $\begin{array}{l}\text { DC pulse, } 2.4 \mathrm{kV} / \mathrm{cm}, 60 \mu \mathrm{s} \\
6 \text {-DMAP }(1 \mathrm{~h}) / 6-\mathrm{DMAP}(1 \mathrm{~h})\end{array}$ & & 16.0 & - & \\
\hline & & ear tissue & & & \\
\hline $\begin{array}{l}\text { Pre- } \\
\text { activation/ } \\
\text { Post- } \\
\text { activation }\end{array}$ & $\begin{array}{l}\text { DC pulse, } 2.4 \mathrm{kV} / \mathrm{cm}, 60 \mu \mathrm{s} \\
6 \text {-DMAP }(0.5) / 6 \text {-DMAP( }(1.5)\end{array}$ & & 16.0 & - & \\
\hline \multirow{4}{*}{$\begin{array}{l}\text { Simultane } \\
\text { ous } \\
\text { activation } \\
\text { and fusion }\end{array}$} & $\begin{array}{l}\text { AC pulse }^{2}, 0.1 \mathrm{kV} / \mathrm{cm}, 3 \mathrm{~s} \\
\text { DC pulse, } 2.4 \mathrm{kV} / \mathrm{cm}, 60 \mu \mathrm{s} \\
6 \text {-DMAP }(2 \mathrm{~h})\end{array}$ & & 16.0 & - & \\
\hline & $\begin{array}{l}\text { AC pulse, } 6 \mathrm{~V}, 600 \mathrm{kHs} \\
2 \mathrm{DC} \text { pulses, } 2.8 \mathrm{kV} / \mathrm{cm}, 30 \mu \mathrm{s}\end{array}$ & & 51.4 & - & \\
\hline & $\begin{array}{l}\text { ionomycin, } 5 \mathrm{mM} / \mathrm{L} \\
\text { cykloheximide, } 10 \mathrm{mg} / \mathrm{ml} \\
\text { cytochalasin } \mathrm{B}, 1.5 \mathrm{mg} / \mathrm{ml}\end{array}$ & foetus & 34.1 & - & $\begin{array}{l}\text { Lagutina } \\
(2000)\end{array}$ \\
\hline & $3 \mathrm{DC}$ pulses, $2.8 \mathrm{kV} / \mathrm{cm}, 30 \mu \mathrm{s}$ & & 47.4 & - & \\
\hline \multirow{4}{*}{$\begin{array}{l}\text { Post- } \\
\text { activation }\end{array}$} & $\begin{array}{l}\text { inositol 1,4,5 triphosphate, } 25 \mu \mathrm{M} / \mathrm{L} \\
\text { 6-DMAP, } 0.2 \mathrm{mM} / \mathrm{L}\end{array}$ & foetus & 29.6 & - & $\begin{array}{l}\text { Mitalipov } \\
\text { (1999) }\end{array}$ \\
\hline & $\begin{array}{l}\text { 2x } 3 \text { DC pulses, } 1.5 \mathrm{kV} / \mathrm{cm}, 60 \mu \mathrm{s} \\
6 \text {-DMAP, } 2 \mathrm{mM} / \mathrm{L}\end{array}$ & & 23.0 & - & $\begin{array}{l}\text { Yin } \\
(2000)\end{array}$ \\
\hline & $2 \mathrm{DC}$ pulses, $2.4 \mathrm{kV} / \mathrm{cm}, 60 \mu \mathrm{s}$ & ear tissue & 18 & - & $\begin{array}{l}\text { Dinnyes } \\
(2001)\end{array}$ \\
\hline & $\begin{array}{l}3 \text { DC pulses, } 3.22 \mathrm{kV} / \mathrm{cm}, 20 \mu \mathrm{s} \\
\text { cykloheximide, } 5 \mu \mathrm{g} / \mathrm{ml} \\
\text { 6-DMAP, } 2 \mathrm{mM} / \mathrm{L}\end{array}$ & cumulus $^{1}$ & 47.0 & 4 & $\begin{array}{l}\text { Chesne } \\
(2002)\end{array}$ \\
\hline
\end{tabular}

${ }^{1}$ genetically transfected

${ }^{2}$ AC-alternating current pulse

${ }^{3}$ DC-direct current pulse

\section{CONCLUSIONS}

The model of artificial activation of reconstructed oocytes is still different from the natural model of activating the oocyte with a penetrating spermatozoon during fertilization. For this reason, artificial activation protocols continue to be modified. The present studies, aimed to improve the artificial activation methods, centre 
mainly around optimizing the parameters of electric field and combining activating agents with blockers of cyclin-dependent kinase or protein synthesis activity. The optimum activation procedure will create conditions for complete reprogramming of exogenous cell nuclei, and thus may help to improve the ultimate efficiency of somatic cloning in farm animals.

\section{REFERENCES}

Baguisi A., Behboodi E., Melican D.T., Pollock J.S., Destrempes M.M., Cammuso C., Williams J.L., Nims S.D., Porter C.A., Midura P., Palacios J., Ayres S.L., Denniston R.S., Hayes M.L., Ziomek C.A., Meade H., Godke R.A., Gavin W.G., Overstrom E.W., Echelard Y., 1999. Production of goats by somatic cell nuclear transfer. Nat. Biotechnol. 17, 456-461

Betthauser J., Forsberg E., Stein M., Childs L., Eilertsen K., Enos J., Forsythe T., Golueke P., Jurgella G., Koppang R., Lesmeister T., Mallon K., Mell G., Misica P., Pace M., Pfister-Genskof M., Strelchenko N., Voelker G., Watt S., Thompson S., Bishop M., 2000. Production of cloned pigs from in vitro systems. Nat. Biotechnol. 18, 1055-1059

Campbell K.H.S., Ritchie W., Wilmut I., 1993. Nuclear-cytoplasmic interactions during the first cell cycle of nuclear transfer reconstructed bovine embryos: Implications for deoxyribonucleic acid replication and development. Biol. Reprod. 49, 933-942

Cheek T., McGuinness O., Vincent C., Moreton R., Berridge M., Johnson M., 1993. Fertilisation and thimerosal stimulate similar calcium spiking patterns in mouse oocytes but by separate mechanism. Development 119, 179-89

Chesne P., Adenot P.G., Viglietta C., Baratte M., Boulanger L., Renard J.P., 2002. Cloned rabbits produced by nuclear transfer from adult somatic cells. Nat. Biotechnol. 20, 366-369

Choi Y.H., Love C.C., Chung Y.G., Varner D.D., Westhusin M.E., Burghardt R.C., Hinrichs K., 2002. Production of nuclear transfer horse embryos by piezo-driven injection of somatic cell nuclei and activation with stallion sperm cytosolic extract. Biol. Reprod. 67, 561-567

Cibelli B., Stice S., Golueke P., Kane J., Jerry J., Blackwell C., Ponce de Leon A., Robl J., 1998. Cloned transgenic calves produced from nonquiscent fetal fibroblasts. Science 280, 1256-1258

Collas P., Fissore R., Robl J., 1993. Preparation of nuclear transplant embryos by electroporation. Anal. Biochem. 208, 1-9

De Sousa P., Dobrinsky J., Zhu J., Archibald A., Ainslie A., Bosma W., Bowering J., Bracken J., Ferrier P., Fletcher J., Gasparrini B., Harkness L., Johnston P., Ritchie M., Ritchie W., Travers A., Albertini D., Dinnyes A., King T., Wilmut I., 2002. Somatic cell nuclear transfer in the pig: control of pronuclear formation and integration with improved methods for activation and maintenance of pregnancy. Biol. Reprod. 66, 642-650

Dinnyes A., Dai Y., Barber M., Liu L., Xu J., Zhou P., Yang X., 2001. Development of cloned embryos from adult rabbit fibroblast: effect of activation treatment and donor cell preparation. Biol. Reprod. 64, 257-263

Galli C., Duchi R., Moor R.M., Lazzari G., 1999. Mammalian leukocytes contain all the genetic information necessary for the development of a new individual. Cloning 1, 161-170.

Gibbons J., Arat S., Rzucidło J., Miyoshi K., Waltenburg R., Respess D., Venable A., Stice S., 2002. Enhanced survivability of cloned calves derived from roscovitine-treated adult somatic cells. Biol. Reprod. 66, 895-900

Ilyin V., Parker I., 1992. Effects of alcohols on response evoked by inositol triphosphate in Xenopus oocytes. J. Physiol. 448, 339-354

Kato Y., Sotomaru Y., Kurokawa K., Kato J., Doguchi H., Yasue H., Tsunoda Y., 1998. Eight calves cloned from somatic cells of a single adult. Science 282, 709-720

Keefer C.L., Baldassarre H., Keyston R., Wang B., Bhatia B., Bilodeau A.S., Zhou J.F., Leduc M., Downey B.R., Lazaris A., Karatzas C.N., 2001. Generation of Dwarf Goat (Capra hircus) clones 
following nuclear transfer with transfected and nontransfected fetal fibroblasts and in vitro-matured oocytes. Biol. Reprod. 64, 849-856

Koo D.-B., Kang Y.-K., Choi Y.-H., Park J.S., Han S.-K., Park I.Y., Kim S.-U., Lee K.-K., Son D.S., Chang W.-K., Han Y.-M., 2000. In vitro development of reconstructed porcine oocytes after somatic cell nuclear transfer. Biol. Reprod. 63, 986-992

Kubota C.H., Yamakuchi H., Todoroki J., Mizoshita K., Tabara N., Barber M., Yang X., 2000. Six cloned calves produced from adult fibroblast cells after long-term cells. Proc. Natl. Acad. Sci. USA 97, 990-995

Lagutina I.S., Mezina M.N., Chernikh V.J., Prokofiev M.I., Galat V.V., 2000. Development potential of rabbit nuclear transfer embryo produced by various fusion/activation protocols. Theriogenology 53, 230 (Abstr.)

Loi P., Clinton M., Barboni B., Fulka J., Cappai P., Feil R., Moor R., Ptak G., 2002. Nuclei of nonviable ovine somatic cells develop into lambs after nuclear transfer. Biol. Reprod. 67, 126-132

Loi P., Ledda S., Fulka J. Jr., Cappai P., Moor R.M., 1998. Development of parthenogenetic and clonal ovine embryos: effect of activation protocols. Biol. Reprod. 58, 1177-1187

Machaty Z., Funahashi H., Mayes M.A., Day B.N., Prather R.S., 1996. Effects of injecting calcium chloride into in vitro-matured porcine oocytes. Biol. Reprod. 54, 316-322

Machaty Z., Wang W.H., Day B.N., Prather R.S., 1997. Complete activation of porcine activation oocytes induced by the sulphydryl reagent, thimerosal. Biol. Reprod. 57, 1123-1127

McCreath K., Howcroft J., Campbell K., Colman A., Schneike A., Kind A., 2000. Production of genetarged sheep by nuclear transfer from cultured somatic cells. Nature 405, 1066-1069

Mitalipov S.M., White K.L., Farrar V.R., Morrey J., Reed W.A., 1999. Development of nuclear transfer and parthenogenetic rabbit embryos activated with inositol 1,4,5-triphosphate. Biol. Reprod. 60, 821-827

Miyazaki S., 1988. Inositol 1,4,5-trioposphate-induced calcium release guanine nucleotide-binding protein-mediated periodic calcium rises in golden hamster eggs. J. Cell Biol. 106, 345-353

Modliński A.J., Karasiewicz J., Boryczko Z., Karczewski W., Jędruch J., Witkowski M., Guszkiewicz A., 2000. Short interval between activation and fusion promotes development of nuclear transfer of sheep embryos (in Polish). Pr. Mat. Zoot. No. 57, 97-102

Onishi A., Iwamoto M., Akita T., Mikawa S., Takeda K., Awata T., Hanada H., Perry A.C.F., 2000. Pig cloning by microinjection of fetal fibroblast nuclei. Science $289,1188-1190$

Ozil J., 1990. The parthenogenetic development of rabbit oocytes after repetitive pulsatile electrical stimulation. Development 109, 117-127

Park K.-W., Lai L., Cheong H.-T., Im G.-S., Sun Q.-Y., Wu G., Day B., Prather R.S., 2001. Developmental potential of porcine nuclear transfer embryos derived from transgenic fetal fibroblasts infected with the gene for the green fluorescent protein: comparison of different fusion/activation conditions. Biol. Reprod. 65, 1681-1685

Polejaeva I., Chen S., Vought T., Page R., Mullins J., Ball S., Dai Y., Boone J.,Walker S., Ayares D., Colman A., Campbell K.H.S., 2000. Cloned pigs produced by nuclear transfer from adult somatic cells. Nature 407, 86-90

Prather R.S., 2001. Basic mechanisms of fertilization and parthenogenesis in pigs. Reprod. Suppl. $58,105-112$

Reggio B.C., James A.N., Green H.L., Gavin W.G., Behboodi E., Echelard Y., Godke R.A., 2001. Cloned transgenic offspring resulting from somatic cell nuclear transfer in the goat: oocytes derived from both follicle-stimulating hormone-stimulated and nonstimulated abattoir-derived ovaries. Biol. Reprod. 65, 1528-1533

Schnieke A.E., Kind A.J., Ritchie W.A., Mycock K., Scott A.R., Ritchie M., Wilmut I., Colman A., Campbell K.H.S., 1997. Human factor IX transgenic sheep produced by transfer of nuclei from transfected fetal fibroblasts. Science 278, 2130-2132

Shiga K., Fujita T., Hirose K., Sasae Y., Nagai T., 1999. Production of calves by transfer of nuclei from cultured somatic cells obtained from Japanese Black bulls. Theriogenology 52, $527-535$ 
Skrzyszowska M., Shioya Y., Nagai T., Geshi M., Takenouchi N., 2000. Development of cloned bovine embryos from nuclei of cumulus and muscle cell origin. Theriogeneolgy 53, 244 (Abstr.)

Skrzyszowska M., Smorąg Z., Kątska L., Ryńska B., Kania G., Gajda B., Kareta W., Jurkiewicz J., 2001. Somatic cloning of goats, embryos reconstruction from skin fibroblasts nuclei (in Polish). Papers of the $2^{\text {nd }}$ Symposium of Polish Society of Reproductive Biology. Warsaw (Poland), p. 55

Swann K., 1993. The soluble sperm oscillogen hypothesis. Zygote 1, 273-279

Tao T., Boquest A., Machaty Z., Petersen A., Day B., Prather R., 1999. Development of pig embryos by nuclear transfer of cultured fibroblast cells. Cloning 1, 55-62

Wells D., Misica P., Tervit H., Vivanco W., 1998. Adult somatic cells nuclear transfer is used to preserve the last surviving cow of the Enderby Island cattle bread. Reprod. Fertil. Develop. 10, 369-378

Wells D., Misica P., Tervit H., 1999. Production of cloned calves following nuclear transfer with cultured adult mural granulose cells. Biol. Reprod. 60, 996-1005

Whitaker M.J., Swann K., 1993. Lighting the fuse at fertilization. Development 117, 1-12

Wilmut I., Schnieke A., McWhir J., Kind A., Campbell K., 1997. Viable offspring derived from fetal and adult mammalian cells. Nature 385, 810-813

Yin X.J., Tani T., Kato Y., Tsunoda Y., 2000. Development of rabbit parthenogenetic oocytes and nuclear-transferred oocytes receiving cultured cumulus cells. Theriogenology 54, 1469-1476

Yin X.J., Tani T., Yonemura I., Kawakami M., Miyamoto K., Hasegawa R., Kato Y., Tsunoda Y., 2002. Production of cloned pigs from adult somatic cells by chemically assisted removal of maternal chromosomes. Biol. Reprod. 67, 442-446

Zakhartchenko V., Durcova-Hills G., Stojkovic M., Schernthaner W., Prelle K., Steinborn R., Muller M., Brem G., Wolf E., 1999. Effects of serum starvation and re-cloning on the efficiency of nuclear transfer using bovine fetal fibroblasts. J. Reprod. Fertil. 115, 325-331

Zuccotti M., Garagna S., Redi C.A., 2000. Nuclear transfer, genome reprogramming and novel opportunities in cell therapy. J. Endocrinol. Invest. 23, 623-629

\section{STRESZCZENIE}

\section{Czynniki indukujące aktywację rekonstruowanych oocytów zwierząt gospodarskich w klonow- aniu somatycznym}

Sztuczna aktywacja rekonstruowanych oocytów indukowana jest dzięki wykorzystaniu różnorodnych czynników natury fizycznej lub chemicznej. Czynniki te mogą być wykorzystywane w różnych protokołach aktywacyjnych, takich jak: pre-aktywacja, aktywacja równoczesna z fuzją i post-aktywacja. Protokół post-aktywacji jest najczęściej stosowany i przynosi najlepsze wyniki w klonowaniu somatycznym zwierząt gospodarskich.

Model sztucznej aktywacji rekonstruowanych oocytów wciąż odbiega od naturalnego modelu aktywowania penetrującym plemnikiem podczas zapłodnienia. W związku z tym protokoły sztucznej aktywacji rekonstruowanych oocytów są wciąż modyfikowane. Obecnie prowadzone badania nad udoskonalaniem metod sztucznej aktywacji skupiają się głównie na optymalizacji parametrów pola elektrycznego oraz łączeniu czynników aktywujących ze związkami blokującymi aktywność cyklino-zależnych kinaz lub syntezy białek. Optymalna metoda aktywacji stwarza warunki do pełnego przeprogramowania egzogennych jąder komórkowych, co może się przyczynić do poprawy końcowej efektywności klonowania somatycznego zwierząt gospodarskich. 